\title{
The Church of Clérigos in Porto as a Baroque Musical Instrument
}

\author{
João Pedro Xavier ${ }^{1}$
}

Published online: 13 May 2017

(C) Kim Williams Books, Turin 2017

\begin{abstract}
This paper considers the Clérigos ensemble in Porto-constituted by the Church, the Hospital, and its iconic Tower-as a powerful Baroque instrument. First, in addition to the ordinary chimes that commanded daily activities in the town, the architectonic and symbolic value of the Tower is underscored by the music produced by its impressive bells. Second, we have the actual heart of the instrument, the Church-Oratory: an acoustic box resulting from the oval plan of the nave and the corresponding dome, with two organs in its head (the apse), symmetrically placed with respect to the main longitudinal axis of the building. I will stress that this kind of space, brought to Portugal by architect Nicolau Nasoni in 1731, conveyed the idea of an Oratory and the musical performance associated with it, and that, significantly, the Oratorians were linked to the chosen plan for Clérigos.
\end{abstract}

Keywords Baroque architecture · Portuguese architecture · Architecture and music · Oratory · Oval plan · Nicolau Nasoni

\section{Introduction}

In the chapter 'The rise of Baroque' of the Histoire de la Musique européenne, Jacques Stehman clearly presents the guiding lines of Baroque and puts music in relation to the other arts:

Baroque is a great liberating explosion, a break from the shapes and forms of the Renaissance. It is the art of ornament and movement, of power and wealth. Baroque is profusion, virtuosity, greatness and often grandiloquence. It is the

João Pedro Xavier

jpx@ arq.up.pt

1 Centro de Estudos da Faculdade de Arquitectura, Universidade do Porto, Rua do Gólgota, 215, 4150-755 Porto, Portugal 
opposite of Classicism: straight lines become curved, serenity gives way to intensity, moderation becomes exhilaration. The sixteenth-century artist submits his creativity to form; the artist in the seventeenth century (and through the mid-eighteenth) submits form to his creativity.

Classicism is defined by the acceptance of an aesthetic form; Baroque improvises, creating unexpected shapes and affirming the preeminence of human impulse over abstract rules that subjugate the work.

If we study the great Baroque creations of the visual arts it is not difficult to establish a parallel with music and verify that musical composition in the seventeenth century is Baroque for the same reasons and according to the same principles: unexpected, broken, whimsical melodic lines (which will give rise to a large instrumental literature of virtuosos), the use of striking contrasts of volume and colorful reliefs (seen for example in the dialogue between soloist and orchestra that amplifies the decorative style and will lead to the Grand Concerto), flexible arabesques in vocal and instrumental lines. In short, intensity of expression coupled with turbulent ornamentation-these are the elements that constitute Baroque Music (Stehman 1978: 111, my trans.).

The characteristics highlighted by Stehman are also recognizable in Baroque spaces in qualities such as dynamism, movement and fluidity, brought by the expanded formal pallet of geometric shapes-generally charged with ornamentation-which are combined in unexpected ways, and colored with a well-balanced use of light and shadow. In contrast to the other visual arts that contribute to create Baroque ambiance, architectural space can also be an enclosure for music, as is the case of a church or other typologies that will rise in relation to the new musical performances that will emerge during the Baroque. Thus, the way music is produced and the acoustic performance of the space, were present in the Baroque architect's mind while the subject was being developed in architectural theory.

In what follows I will consider the relationship between music and architecture, taking in consideration that space is the inevitable and most direct link of both arts, making it possible to understand a building as a musical instrument.

A building like Clérigos, as churches in general, might properly be considered a musical instrument, first because of the role of music in religious ceremonies, and then because of the acoustic qualities of the space. I am not considering proportional relationships that led Robert Fludd to propose an ideal Pythagoric-Neoplatonic musical building, like the Concordia Templum (Fludd et al. 1618: 168-169), although these ideas will reverberate in the Baroque period. ${ }^{1}$ This intellectual tradition, based on musical analogy, where both architecture and music are reflections of the mathematical order of the cosmos, synthesized in Goethe's wellknown expression that 'architecture is frozen music' (Goethe 1839: 282), will not be my main concern. Instead, I am going to look for affinities and reciprocal conditioning between architecture and music, derived from space (Xavier 2013). These are the kind of questions that allow us to detect the symbiosis between the

\footnotetext{
${ }^{1}$ Incidentally, in addition to shape, proportion cannot be ignored with respect to acoustics; this is a very obvious concern, for instance, in Wren's discourse (Wren et al. 1750: 318-321).
} 
space of the Church of Notre-Dame de Paris and the polyphonic music of Pérotin (c. 1170-c. 1236), the space of the Church of St. Mark in Venice (with its resonant domes) and the technique of cori spezzati taken to its summit with the music of Giovanni Gabrielli (c. 1557-1612), the space of the Church of St. Thomas in Leipzig and the music of the cantatas and passions of Bach (1685-1750), to cite only a few historic examples. ${ }^{2}$

Geographically and temporally close to Clérigos, I cannot fail to mention the paradigmatic case of the Basilica of Mafra, whose first stone was laid in 1717 (Pimentel 2002: 127), the crown jewel among the creations of King João V (1689-1750). Conceived by João Frederico Ludovice ${ }^{3}$ (1673-1752), it was designed to have six organs, like the Escorial of Juan de Herrera! Composers João Sousa Carvalho (1795), António Paqua Puzzi (1805), João José Baldi (1807), Marcos Portugal (1807), António José Soares (1807), and António Leal Moreira (1807?), created music expressly intended for that space. Already classic, given the late completion of the six organs, these composers were aware of the full potential of this architectural musical instrument, unique in the world. A recent intervention to restore the organs has made it possible to hear the sound once again on all its fullness.

\section{Clérigos Ensemble}

The Church of Clérigos, designed by Nicolau Nasoni, ${ }^{4}$ was recently given back to the city of Porto, after a long and careful restoration process. The results of this gift are already evident (Figs. 1 and 2). And we are just in the beginning - a new beginning! What we have restored to us is both a remarkable monument and an extraordinary musical instrument.

First of all, I should point out its iconic Tower and the music produced by its impressive bells. What we can appreciate and hear now is a carillon with 49 bells installed in 1995, which transformed the tower into a beacon of music! Many concerts were performed from then on, confirming this status. Originally, the range of sounds was not as complete as it is now, because the number of bells was much smaller. When the Tower was concluded in 1763, it had already a number of bells baptized with the name of Saints; some more were added during the next century. We know that, in 1860, it had ten bells, the largest of which was melted in 1781 (Hierro Lopes et al. 2013: 259). The bells were used to announce the time, and the beginning of regular or exceptional services and other events, and we can imagine

\footnotetext{
${ }^{2}$ For instance, in contemporaneity, this intimate relationship is highly invigorated by Xenakis, Stockhausen and Pierre Boulez.

3 This is the Portuguese Italianized name of the Swabia born Johann Friedrich Ludwig.

4 Niccoló (Nicolau in Portuguese) Nasoni was born in San Giovanni Valdarno di Sopra, in 1691, died in Porto, in 1773, and is buried in Clérigos Church. He arrived to Porto in 1725 as quadrature painter, and firstly worked in the Cathedral. Then, he gradually became an architect with some majors works in Porto. More information about Nasoni can be found online:

https://sigarra.up.pt/up/en/WEB_BASE.GERA_PAGINA?p_pagina=edif\%C3\%ADcio\%20da\%20reitoria\% 20-\%20enquadramento\%20-\%20obras\%20de\%20refer\%C3\%AAncia\%20-\%20nicolau\%20nasoni.
} 


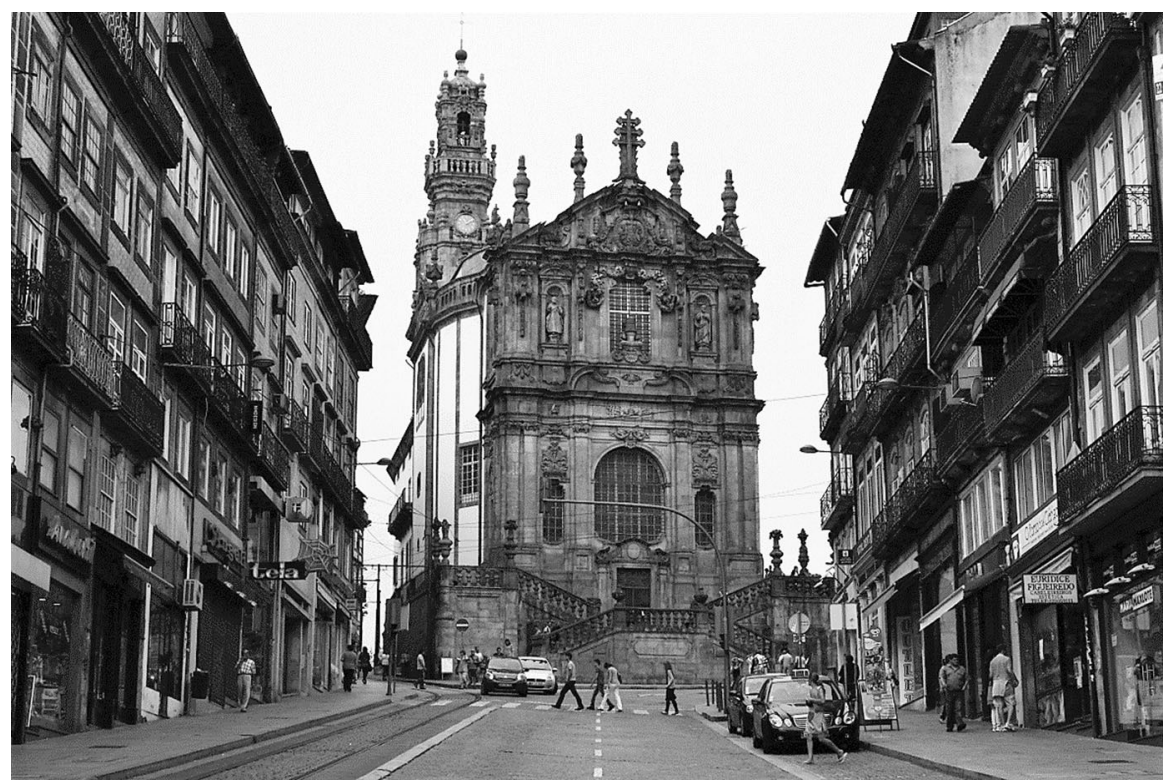

Fig. 1 The main façade of the Clérigos Church in Porto. Nicolau Nasoni, 1731-1763. Photo: author

how powerful its chimes were on the most solemn occasions. Carved into the stone, at mid-height of the Tower's West façade, is the maxim Laudate eum in jubilationis cymbalus ('Praise him with resounding bells', Psalm 150: 5).

Then we have the actual soul of the instrument: the Church (Fig. 3).

An acoustic box, resulting from the oval plan of the nave, with two pipe organs in its head (the apse), symmetrically disposed with respect to the main longitudinal axis of the building. If we add to these organs, whose sound fills the space, a choir and an orchestra, then we understand the reasons that allow us to look to this Church as a powerful musical instrument-more precisely, a Baroque musical instrument. Actually, it remains a Baroque instrument to this day, in spite of the transformations to Nasoni's original design.

One reason is, obviously, the role of the two Baroque pipe organs (Fig. 4), though we must be aware of their Iberian provenance, which means, for instance, that we must carefully select the repertoire and look for Iberian composers like Carlos Seixas (1704-1742) or Antonio Soler (1729-1783), whose sonatas are clearly suitable for these instruments and resonate beautifully in the space.

However, the main reason might be what I considered to be the soul of this instrument: the shape of its space, that is, its particular geometry. As an oval church, the first one built in Portugal, Clérigos can, in fact, be considered an acoustic box: an oval cylinder crowned by an oval dome (Fig. 5). ${ }^{5}$

To this dome are connected, at the ends of the major axis, the entry's gallery above the choir and the apse with the organs. Both are cuboid spaces with vaults,

\footnotetext{
5 In Portugal, there is a sole precedent of an oval space: the chapter room of the Mafra Convent, designed by Ludovice.
} 


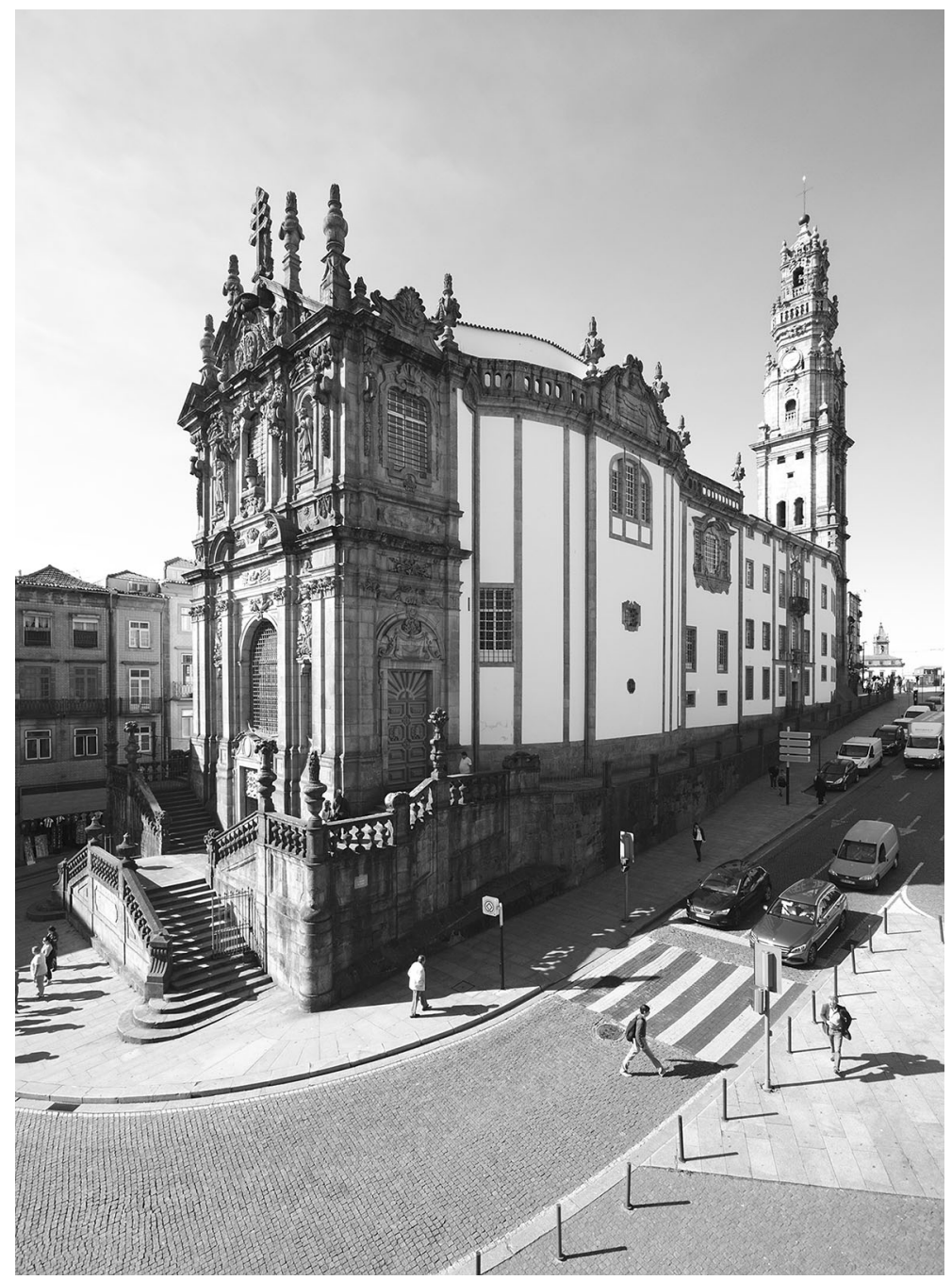

Fig. 2 General view of the Clérigos complex in Porto. Photo: Pedro Varela, reproduced by permission

linked to the nave with arches, which invade the ellipsoidal surface, reinforcing continuity and longitudinal spatiality. At the ends of the minor axis we find the sources of natural light: two windows borrowed from Guarini, as detected by Robert Smith (1966: 91). There are, however, several peculiarities.

I should make a remark at this point regarding the question of oval vs. elliptical layouts. Both curves appear in the architectural treatises of that time, and the terms "oval" and "ellipse" are used to refer to each of them without distinguishing between them. However, it is also then that the language and concept finally stabilize. When certain conditions are met-that is, if the lengths of the major and 
Fig. 3 Clérigos church with its oval dome. Photo: Pedro Varela, reproduced by permission

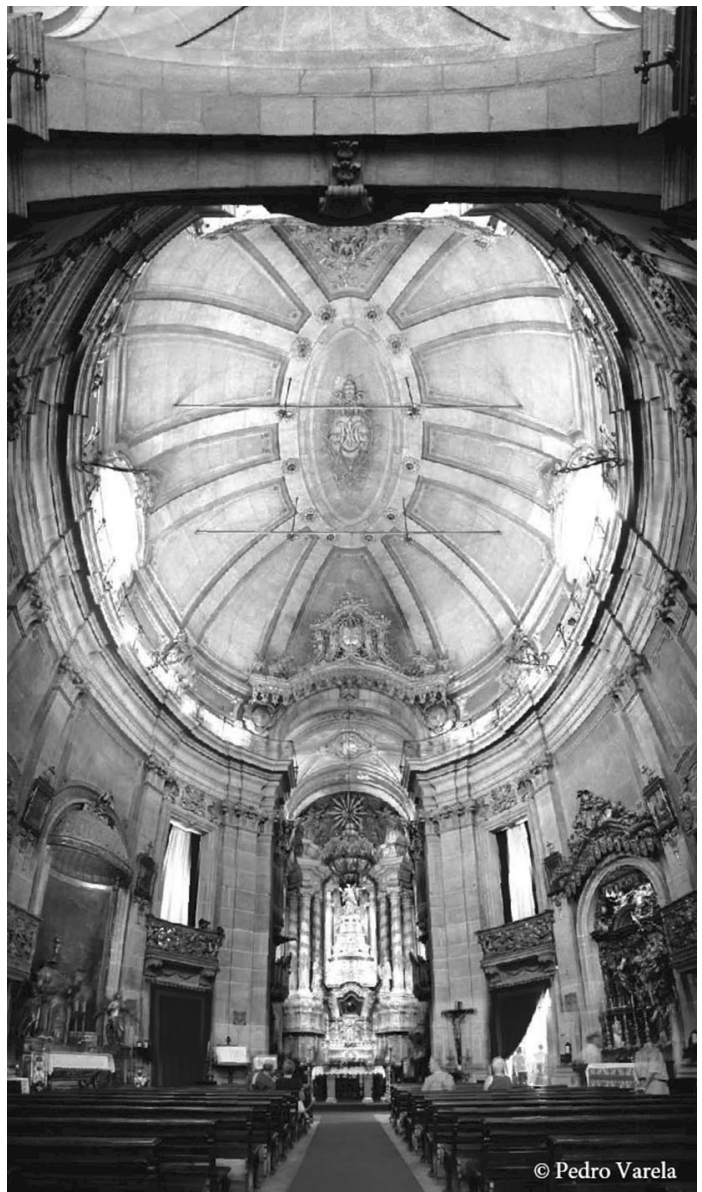

the minor axis on both curves are well-balanced ${ }^{6}$ - it is a fact that oval plans overlap elliptical plans almost perfectly. According to Ana López Mozo, Caramuel de Lobkowitz (1678: IV, 28) "was the first among the authors of architectural treatises to apply the names of oval and ellipse correctly; Caramuel describes the oval as an imperfect ellipse” (López Mozo 2011: 569).

\section{Acoustics and the Conics: The Elliptical Layout}

Thinking about acoustics it should be noted that, at the time, a place of privilege was generally reserved for spaces generated from conic sections. I am referring in particular to the ellipse (or the equivalent oval), the parabola and the hyperbola.

\footnotetext{
6 "... an oval was, then, a curve formed from circular arcs which approximates the ellipse of the same axes", states Santiago Huerta (2007: 211). For more about the similarities and differences between ovals and ellipses, see (Duvernoy 2015, esp. p. 193). Paul Rosin (2001) studies the fidelity of ovals constructed by means of some historical methods to true ellipses.
} 


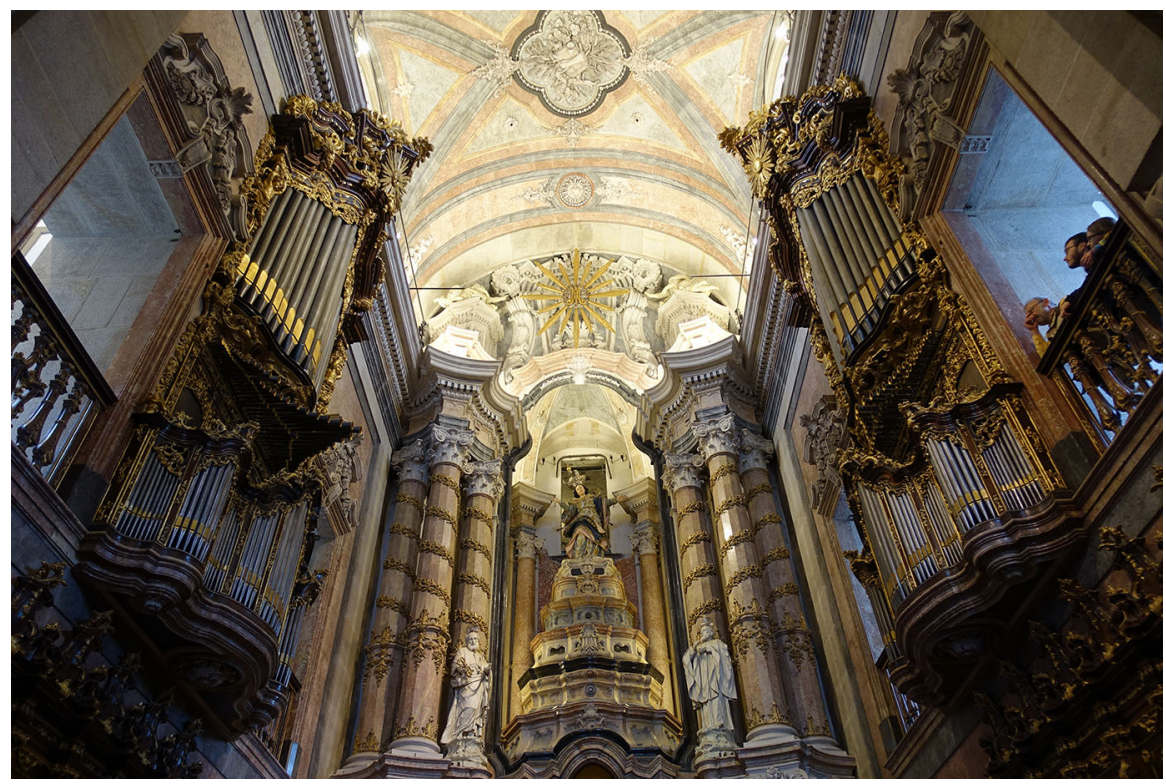

Fig. 4 The apse with the two Baroque organs. Photo: author

Two important authors, Marin Mersenne in Harmonicorum libri (Mersenne 1635) and Athanasius Kircher in Musurgia Universalis (Kircher 1650), advocate the superiority of these shapes for broadcasting sound, whose path in space was identified with light (Hersey 2000: 31-32). Mersenne refers, in particular, to the advantages of semi-elliptical, semi-parabolic and semi-hyperbolic layouts; Kircher does not omit any possibility and elaborates on the nature of elliptical, parabolic and hyperbolic layouts, and their volumetric expressions, which he named elipsoplastes, paraboloplastes and hyperboloplastes, respectively. Furthermore, Kircher underscores the qualities of the elliptical space crowned with an ellipsoidal dome, and provides a schematic illustration of sound behavior (Fig. 6). He also recommends that the surface should be polished, like a mirror, to ensure perfect reflection.

We cannot be sure if Nasoni was aware of this information but since at the time these spaces enjoyed a good reputation with regards to acoustics, I believe that they would be obvious choices for setting up a church-oratory.

Regarding the treatment of the dome surface I believe it possible that Nasoni might have thought about a quadrature, as in St. Anthony Church of the Portuguese ${ }^{7}$ in Madrid, designed by Pérez Sánchez in 1623 (Gomes 2001: 182-185). There exists a preparatory drawing for that quadrature by Dionisio Mantuano, from the 1660s (not used for the actual painting), which we can imagine laid upon Clérigos dome, with the necessary adaptations (Fig. 7).

Curiously, Nasoni himself, in the Magistral Palace of the Order of Knights Hospitaller in La Valletta, had already experimented by means of a quadrature on a flat ceiling the interplay between an ellipsoidal and a spherical dome (1722-1725);

\footnotetext{
7 This church is known, since 1668 , as St. Anthony of the Germans.
} 
Fig. 5 Clérigos Brotherhood

plan. Image: João Carlos Santos, reproduced by permission

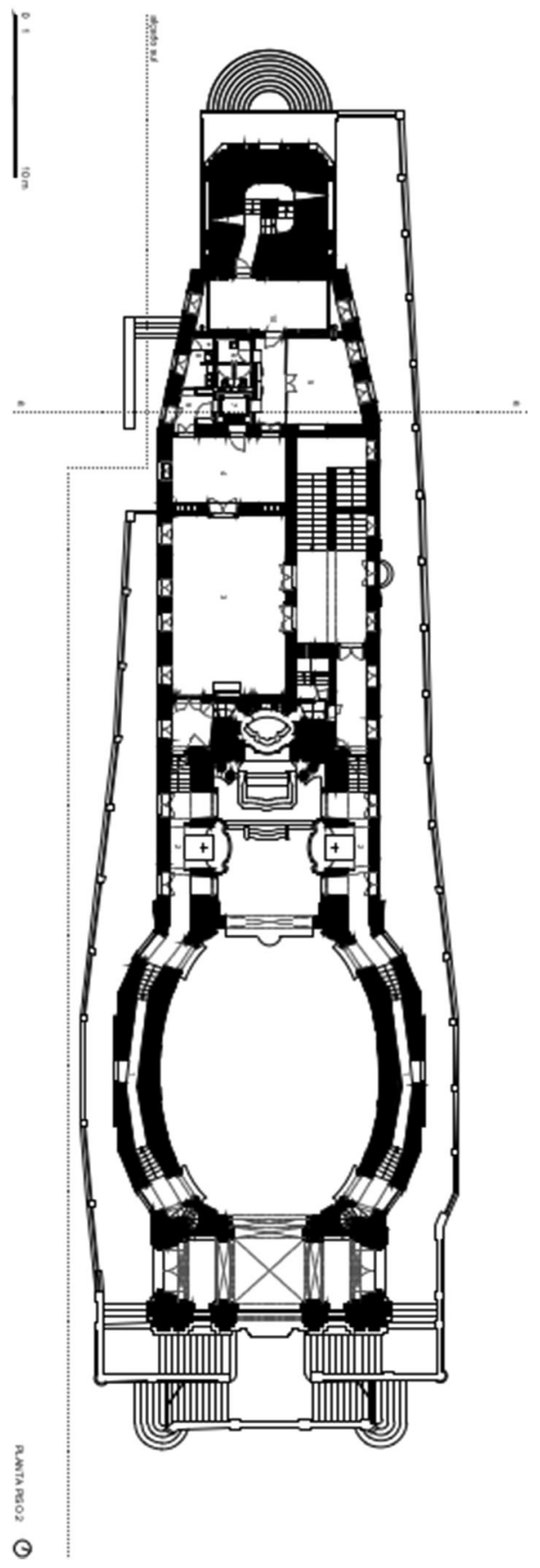




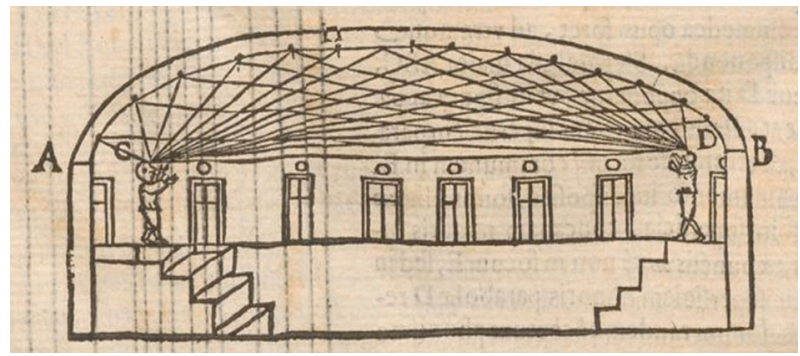

Fig. 6 Acoustic behavior of a semi-elliptical dome. Image: (Kircher 1650: 300)

in Clérigos, he was finally able to build an actual oval dome in brick. The entirety of the stucco work that we see now, which is precisely the opposite of the "polished 'surface desired by Kircher, is a late addition carried out in 1884-85 (Hierro Lopes et al. 2013: 318-325), and simulates the existence of diagonal ribs in granite interspersed with marble, converging to a small oval shape in the center.

This sublimation of acoustics, together with visual qualities of the elliptical plan, is not limited to sacred architecture. For what might be considered the Baroque spectacle par excellence-the opera-there will be created a new type of building, which, given its origins, will be known as Teatro all'italiana. The refinement of this architectural type proceeded hand in hand with the development of this burgeoning genre, a great phenomenon with huge social repercussions, and great economic impact.

At the height of Italian theater, when variations in the shape of the auditorium and its articulation with the proscenium arch and the stage had already been experimented, Pierre Patte presents, in his Essai sur l' Architecture Théatrale (1782: 154-165), the elliptical plan as the most suitable for the shape of the auditorium (Fig. 8). Curiously, he admits the use of the oval figure, which he considers much better than the racket, the horseshoe, the bell, the circle, the semi-circle and semioval. He remarks that the oval's approximation of the ellipse is the reason for its advantage (Patte 1782: 156), but even so, nothing surpasses the proper ellipse:

... convenons qu'il n'y a que la figure elliptique seule que l'on puisse attendre tout le succès désiré (let us agree that it is only the elliptical figure alone that one can expect all the desired success) (Patte 1782: 157).

This is precisely the shape that will be adopted for the auditorium at the Real Teatro de São Carlos in Lisbon, built according to the design, already neoclassical, of José da Costa e Silva (1747-1819). Carneiro (2002: Vol. 1 187-193) demonstrates that in São Carlos there is a very close relation to the ellipse of Patte, in addition to other important affinities with the Teatro alla Scala in Milan (Fig. 9).

The response from Porto was immediate, and the Real Teatro de São João, designed by Vicente Mazzoneschi, might also have had an elliptical plan, as hypothesized by Carneiro (2002: Vol. 1 245-248). In this case, the source has to have been São Carlos, on which Mazzoneschi had worked as a decorative painter. 


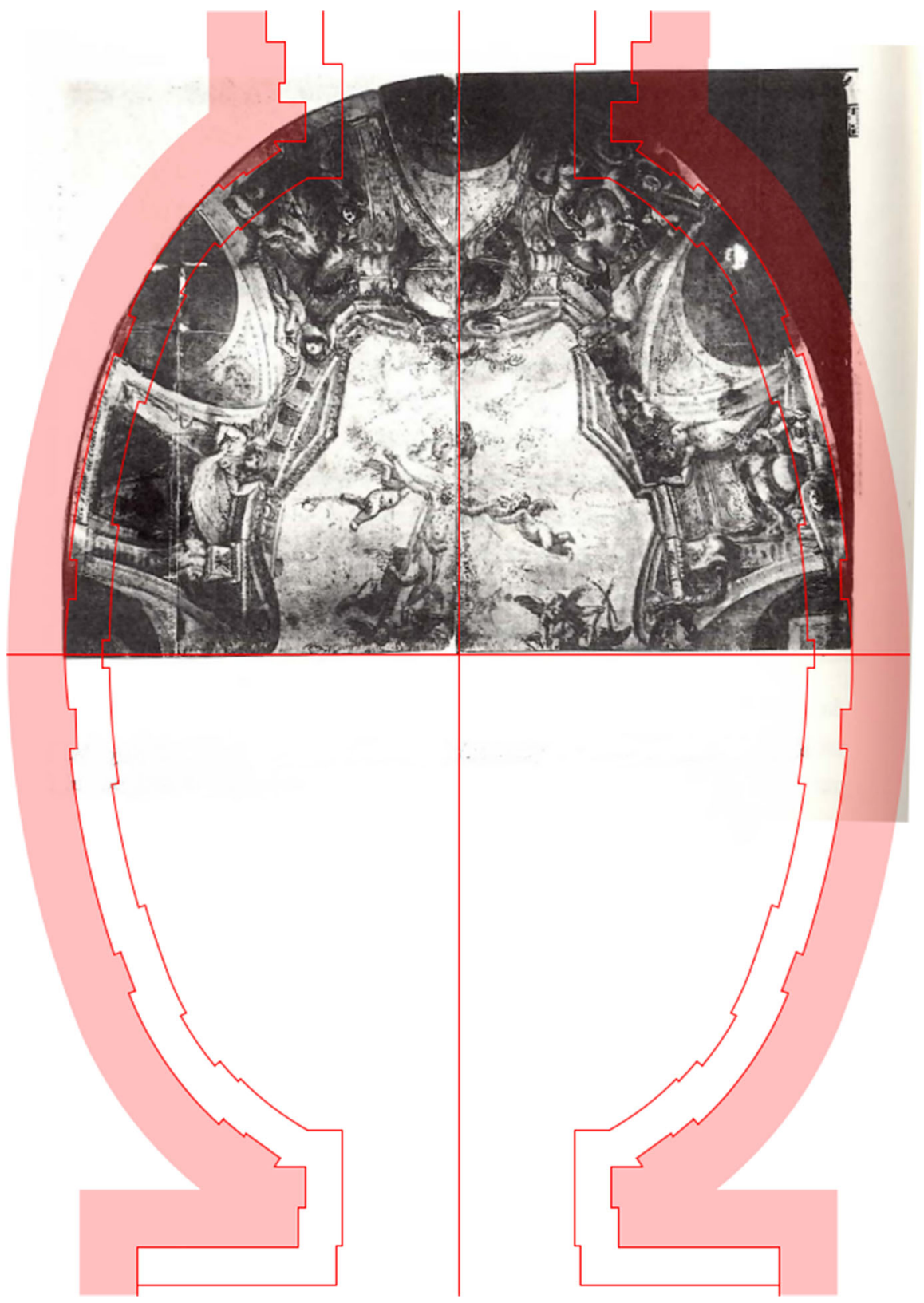

Fig. 7 Mantuano's quadrature laid upon Clérigos dome. Images: (Gomes 2001: 194) and (Varela 2006: 116), reproduced with permission

Paradoxically, when the two largest cities of the Portuguese kingdom finally earned a decent public theater-São Carlos is comparable with theaters of other European capitals-that is, a true Opera Theater, a genuine Baroque creation-the 


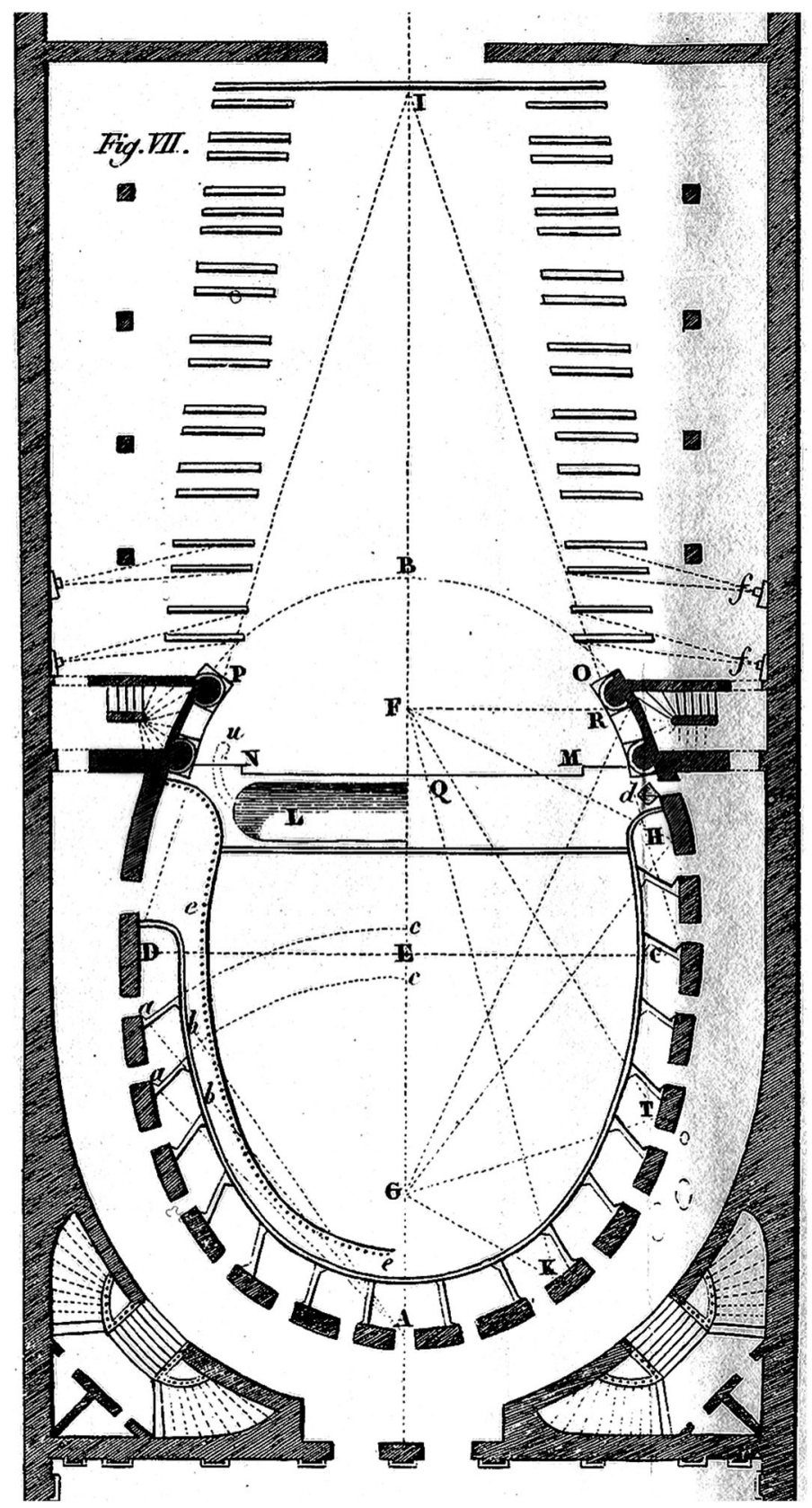

Fig. 8 Patte's ellipse. Image: (Patte 1782: Fig. VII) 
(b)

(a)
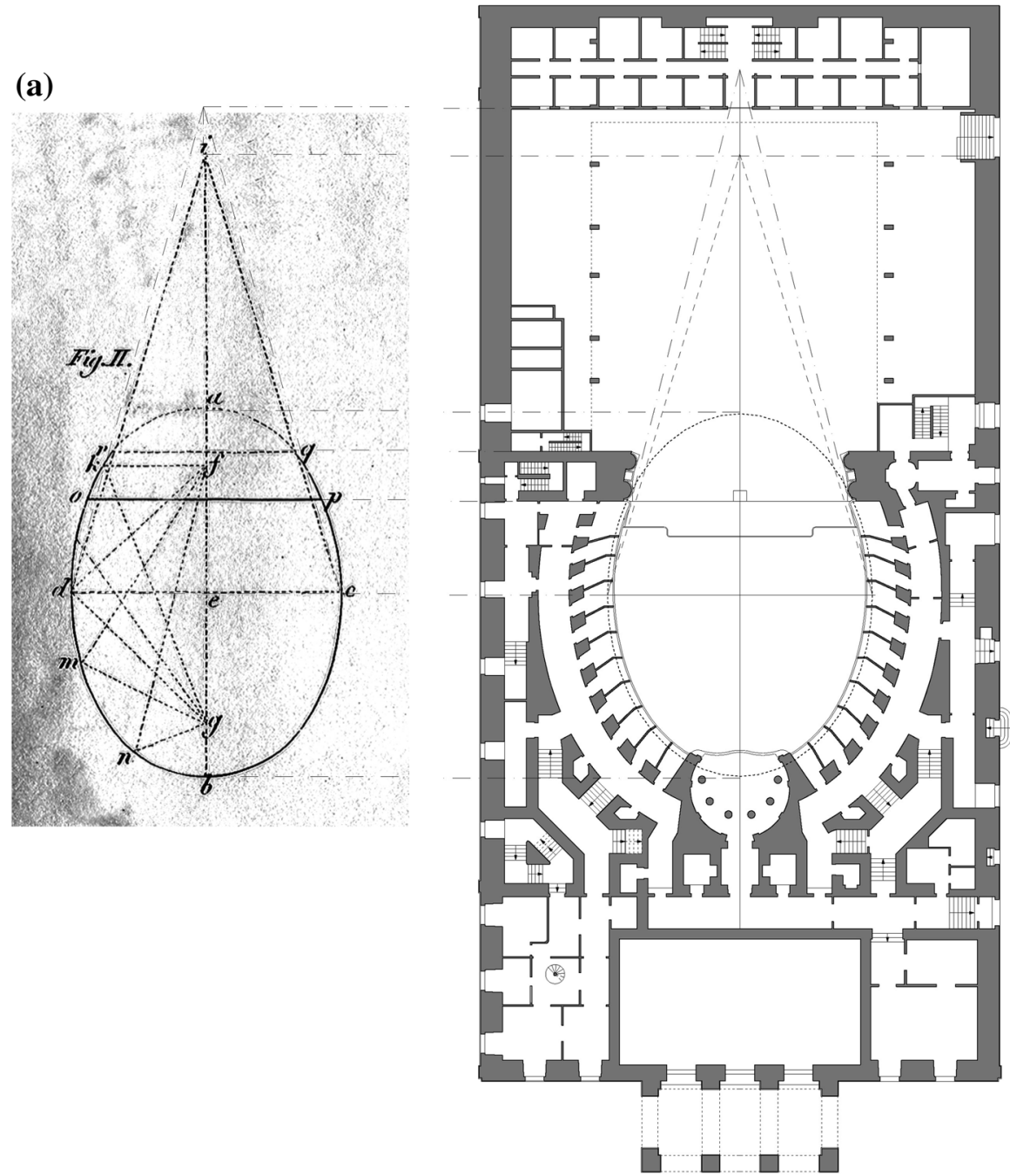

Fig. 9 Comparing Patte's ellipse (a) with that of the São Carlos auditorium (b). Images: (Carneiro 2002: Vol. 1, 213), reproduced with permission

music, along with the architecture, had already evolved into a style that can be called Classicism or Neoclassicism.

The theater that was the symbol of the golden age of Baroque opera in Portugal, the Ópera do Tejo, or Royal Opera House, erected by King José I, and designed by Carlo Sicinio Galli-Bibiena (1717-1760), existed for only seven fleeting months, as it was reduced to rubble in the 1755 earthquake. Although it is not possible to reconstruct the auditorium, because we only have the plan of the foundation, it is however possible to make the claim that it was approximately elliptical, as it was 
the Real Teatro in Salvaterra de Magos (1753), where, not coincidentally, the auditorium vault is very close to an ellipsoidal surface.

Thus, the formalization of Patte's ideas, as often happens with architectural theory, was not only based on existing theory but surely taken from some successful architectural examples where the room configurations tended to be approximately elliptical.

Abbot António da Costa, who left the country in 1749, already speaks of this kind of room shape, when he laments the absence of an Italian theater in the city of Porto. In a letter sent from abroad, he writes:

The theater from outside, or the house where people are [о а casa em que a gente está], you see, is very large and very high in relation to the theater inside; it is oval and has six floors of boxes. For Your Mercy to understand a little about the character of both theaters, suppose it is like St. Ildefonso Church, or as Clérigos. The action takes place in the apse; and people are on the ground, called parterre, or inside the boxes (Carneiro 2002: Vol. 1 45, my trans.).

This reference to St. Ildefonso and Clérigos is rather interesting because, though they are different, they share some similar characteristics (Fig. 10).

Regarding the sacred space, we know that in Portugal the oval layout was a late arrival, while the famous rectangular layout with chamfered vertices, actually an irregular octagon, was common.

In Porto, this plan appears in St. Ildefonso Church, located on the top of the Cimo de Vila hill (Batalha square); on the opposite side, on the top of Olival hill (Cordoaria garden), just after the conclusion of the construction of St. Ildefonso, the construction of Clérigos was about to begin (Fig. 11). The first, significantly, is by a Portuguese architect, the second, by an Italian.

As José Fernandes Pereira notes:

Basically, this is a confrontation between two ways of understanding the Baroque, the latter: more dynamic and audacious; the former: more static and embedded in tradition (Pereira 1993: 33, my trans.).

The prestige of the oval plan, proposed by Antonio da Sangallo, Peruzzi and Serlio, and first materialized by Vignola at Sant'Anna dei Palafrenieiri in 1565-in Sant'Andrea in Via Flaminia of 1553 only the dome has an oval layout-will be emphasized with the evolution of Mannerism, reaching its maximum expression in full Baroque, with Borromini and Bernini. Their influence, tempered by the ars combinatoria of Guarini (Norberg-Schulz 1977: 295), would extend to Central Europe, allowing truly innovative compositions, well represented, for example, by the work of Balthasar Neumann (1687-1753).

As a single space, it will often be preferred for use as an Oratory, it being no coincidence that, for example, the Oratorio de S. Felipe Neri in Cádiz, by Blas Díaz, shows this configuration (Fig. 12). 

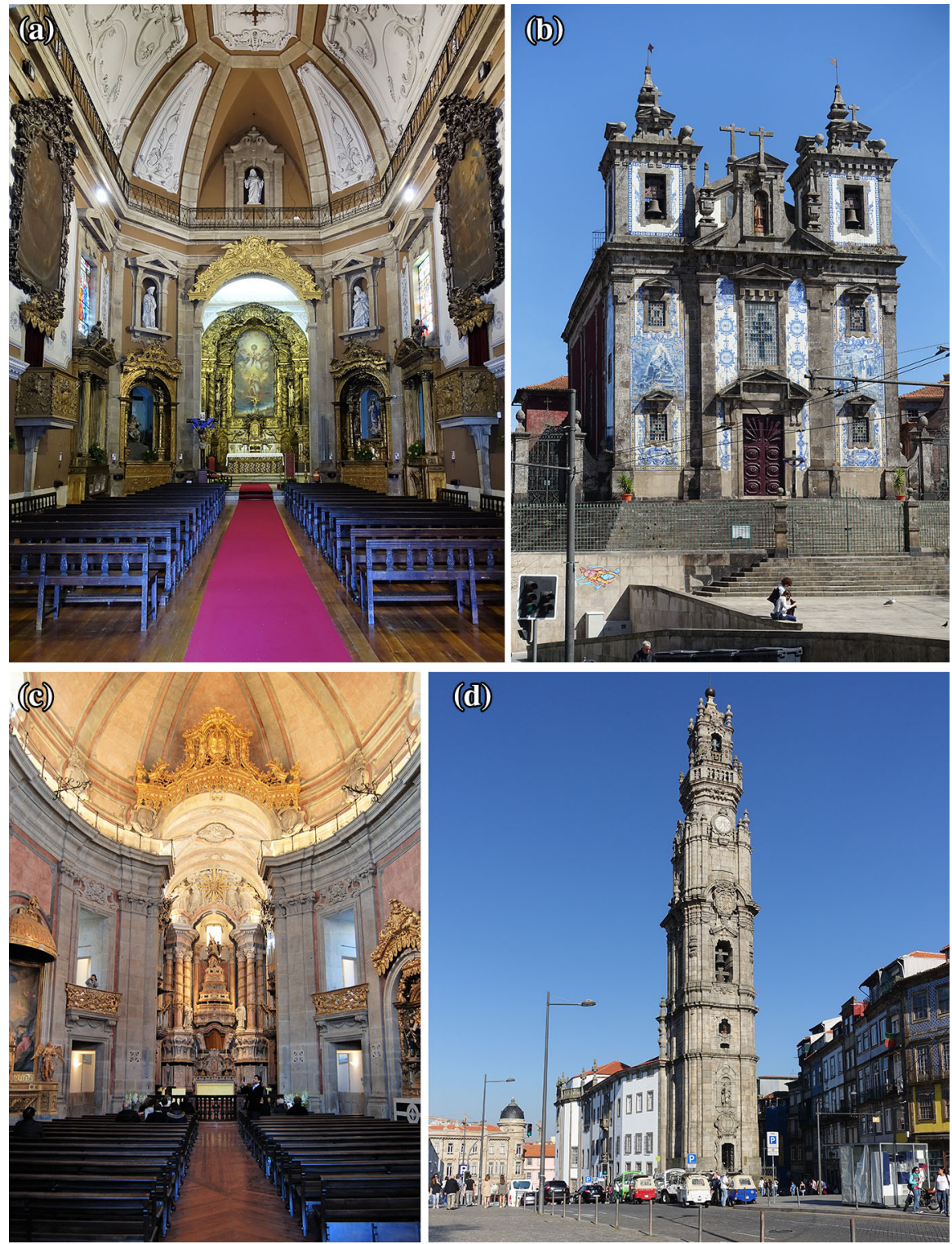

Fig. 10 St. Ildefonso Church (1717-30): interior (a), exterior (b) vs Clérigos Church (1731-63): interior (c), tower (d). Photos: author

\section{The Congregation of the Oratory and the Oratorio dei Filippini}

The Congregation of the Oratory founded by St. Philip Neri, known as the Oratorians, recognized by Pope Gregory XIII in 1575, was settled in the Chiesa di Santa Maria in Vallicella, after inhabiting the three-nave basilica of San Giovanni 


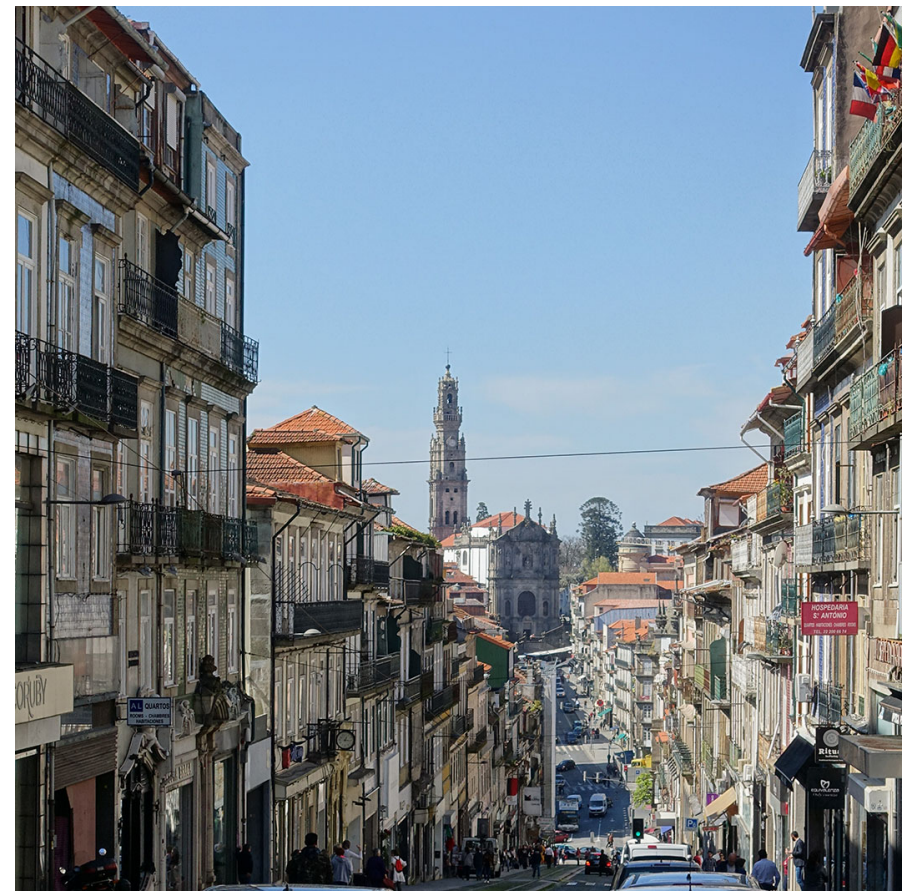

Fig. 11 Clérigos ensemble viewed from St. Ildefonso Church. Photo: author

dei Fiorentini (1523-1734) where Philip Neri became rector in 1565. But although the Chiesa Nuova in Vallicella approached the model advocated by Carlo Borromeo, epitomized in Il Gesù, there was soon felt the need for a differentiated space, capable of attracting a wider audience. This gave rise to the Oratory, which was intended to serve as an antechamber, or we might say a stepping-stone, into the Church. Therefore, it is not surprising that in the 1640s, Borromini was called to reshape the entire complex of the congregation and design a new space: the Oratorio dei Filippini, adjacent to the Church. ${ }^{8}$

Borromini's Oratory is a cuboid space whose vertical edges are subtly chamfered with a pilaster, promoting the continuity of the parietal planes that shape the space, within which the altar plane, where the tribunes for the singers and the organ are located, is emphasized through the use of detached columns instead of pilasters. Although this is just a hint, it is more than sufficient to enhance continuity and emphasize the central space. The dome, in turn, is attached to the walls through diagonal ribs that are connected to the pilasters and define a crossover network that is both interrupted and linked by an oval ring. Meanwhile, the façade is curved to embrace the people and invite them to come and follow the congregation's ideals of charity.

It turns out that during the Counter-Reformation, one of the main strategies of persuasion, coupled with the strength of architecture, painting and sculpture, was

\footnotetext{
${ }^{8}$ See: http://www.laboratorioroma.it/ALR/Oratorio/Immagini/sala_organo.jpg.
} 

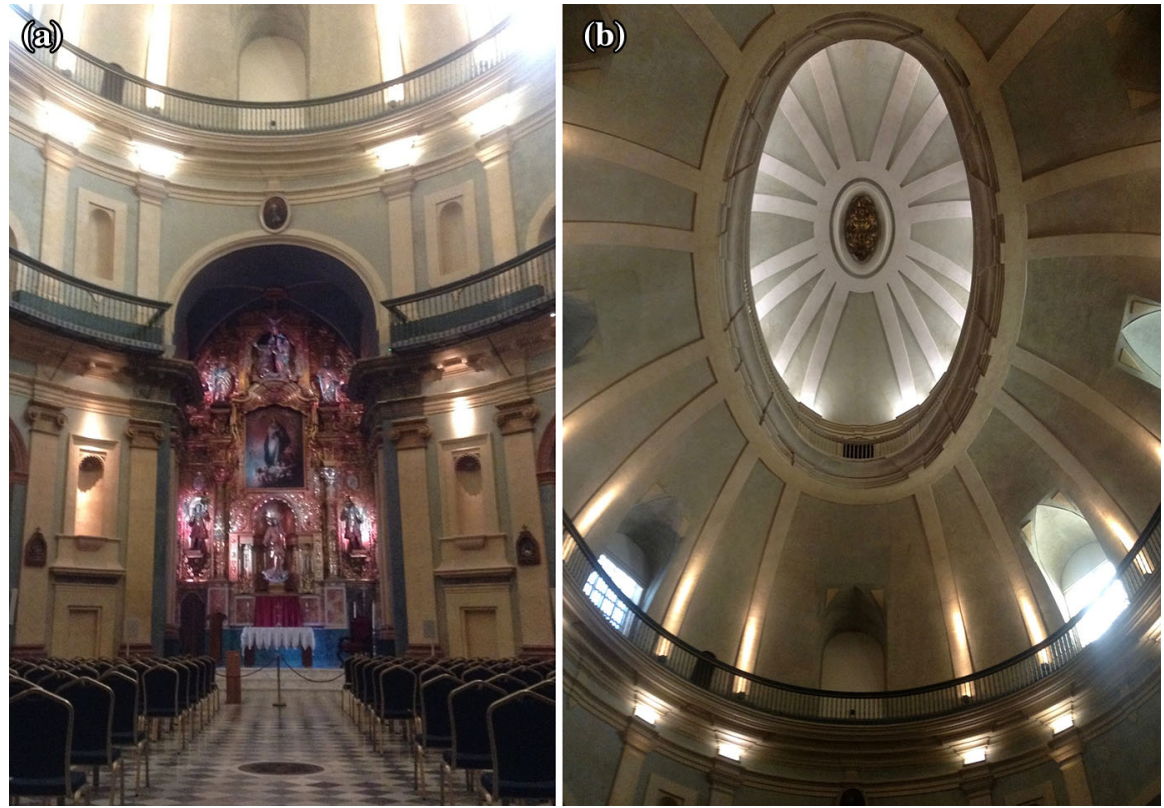

Fig. 12 Oratorio de S. Felipe Neri, Cádiz. Blas Díaz, 1685-1719 and Pedro Afanador, 1764. Photo: author

music. Further, the time and the circumstances were just right for the emergence of a new musical genre: precisely, the Oratorio, a Baroque creation that is derived from Laudi Spirituali promoted by St. Philip Neri, which were composed and performed by the congregation musicians, and linked to the spirit of the age. Taking the name from the space it was conceived for, the term 'Oratorio' would later come to designate any lyrical and dramatic work based on a religious text: 'it is almost a sacred opera' (Stehman 1978: 139-140).

In addition to Neri's initial impulse, there is no doubt that the Oratorio dei Filippini, conceived by Borromini, plays a natural role in the settling of this new musical genre, being Pasquini's Oratorio di Sant'Alessio, composed in 1675, considered a keystone for the refinement of the oratorio genre.

Ten years after the debut of Sant'Alessio, two geniuses were born: Bach (1685-1750) and Handel (1685-1759). Both will immortalize the oratorio, as indeed, they did with almost all musical genres that they explored.

It is worth looking more closely into Handel because through his work we can verify how the path of the oratorio-which as we have seen, is combined with a specific space: the oratory-will ultimately determine the creation of a new type of space for music performance: the concert hall. In fact, we owe to Handel, working jointly with Thomas Camplin, the design and building of the oldest concert hall we know: the Holywell Music Room in Oxford (1748), expressly designed for the performance of his oratorios, including The Messiah (Bagenal and Wood 1931: 98). The Holywell Music Room layout is rectangular but has, on the stage back wall, a 
sort of apse of approximately parabolic shape, which leads us to recall the recommendations of Mersenne and also Kircher.

The Camplin building, however, would hardly be Baroque. We are in England, the country of Palladianism. This is a style that will arrive soon to Porto, when the final stones of the Tower of Clérigos are still fresh. Two buildings built there, the St. Anthony Hospital by John Carr (1770) and the British Factory House (1785) by John Whitehead, opened the door to a new Palladian taste that pleased the bourgeoisie, but did not attract the clergy; it would take even more time to be accepted by the Royal court.

In Porto, we had to wait until the twenty-first century, to have a true concert hall: the already famous Casa da Música (2005), by Rem Koolhaas.

\section{The Church of Clérigos}

In addition to Roman churches, among which we should point to San Giacomo in Augusta (1592-1602) by Carlo Maderno, Nasoni would get to know, during in his stay in Malta, the St. James Church (1709-1710) in Valletta by Romano Fortunato Carapecchia (De Lucca 1999: 120-123), which will be decisive for his choice in the design of the Church of Clérigos, dedicated to Our Lady of the Assumption.

Pedro Varela, after performing a thorough survey of Clérigos, ${ }^{9}$ began his architectural analysis of the church by trying to fit an ellipse on the plan, but without success (Varela 2006: 84-85). Then he concluded that the layout of the church is an oval figure with four centers (Fig. 13) that are related according to the following rules: the two centers of the arcs with larger radius equals the distance of the major axis $^{10}$; the other two centers of the arcs with smaller radius divides each semi-major axis in extreme and mean ratio. ${ }^{11}$ In confirmation of Nasoni's preference for this kind of oval shape, Varela also discovered that he had already used it in two niches in Porto's cathedral, where he worked after his arrival from Malta, in 1725 (Varela 2006: 87-89).

However, the use of the golden ratio to place the centers on each semi-major axis, ${ }^{12}$ might have come from Carapecchia (Fig. 14), as proposed by Varela (2006: 89), reinforcing the connections between the churches of St. James and Clérigos, beyond their well-known stylistic affinities (Smith 1966: 89). At least, Carapecchia might have been the intermediary between Borromini and Nasoni. In fact, the main source must be Borromini, because there is a very close relationship between the shape of the impost oval dome of San Carlino, ${ }^{13}$ and the oval layout of Clérigos

\footnotetext{
9 This survey was performed using traditional processes and instruments, and the measurements were taken using a laser measuring device.

10 This first rule was found in late Gothic German documents by Koepf as remarked by Santiago Huerta (2007: 222). See, in Huerta's paper, the drawing on the left in Fig. 16(b).

11 The small oval on the center of the dome is not related to Nasoni's original design, as noted before.

12 Only a survey will allow us to confirm this hypothesis.

13 This impost oval is studied by Mazzotti (2014: 389-392).
} 
(a)

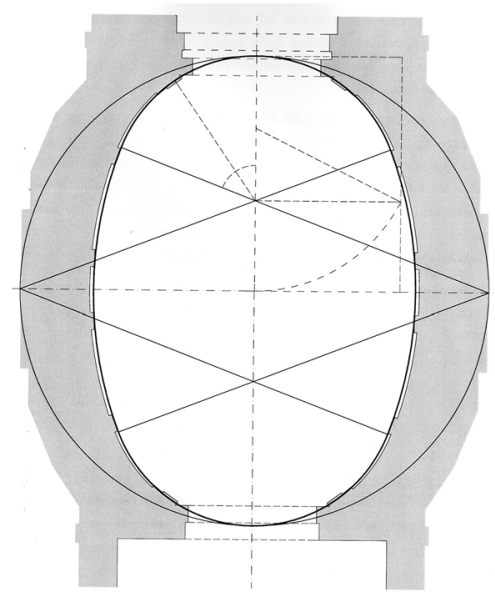

(b)

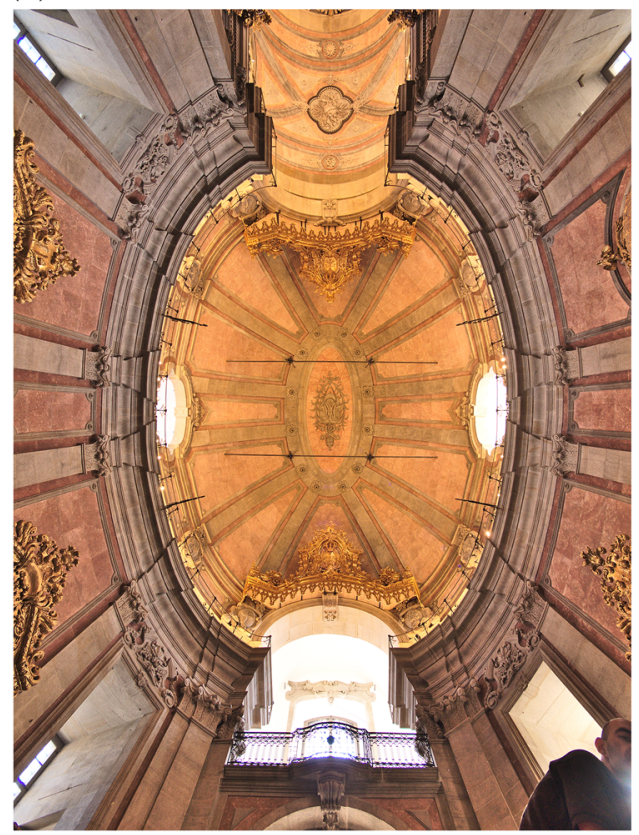

Fig. 13 Clérigos oval plan (a) and its dome (b). Image: Pedro Varela (2006: 88); Photo: Pedro Varela, reproduced by permission
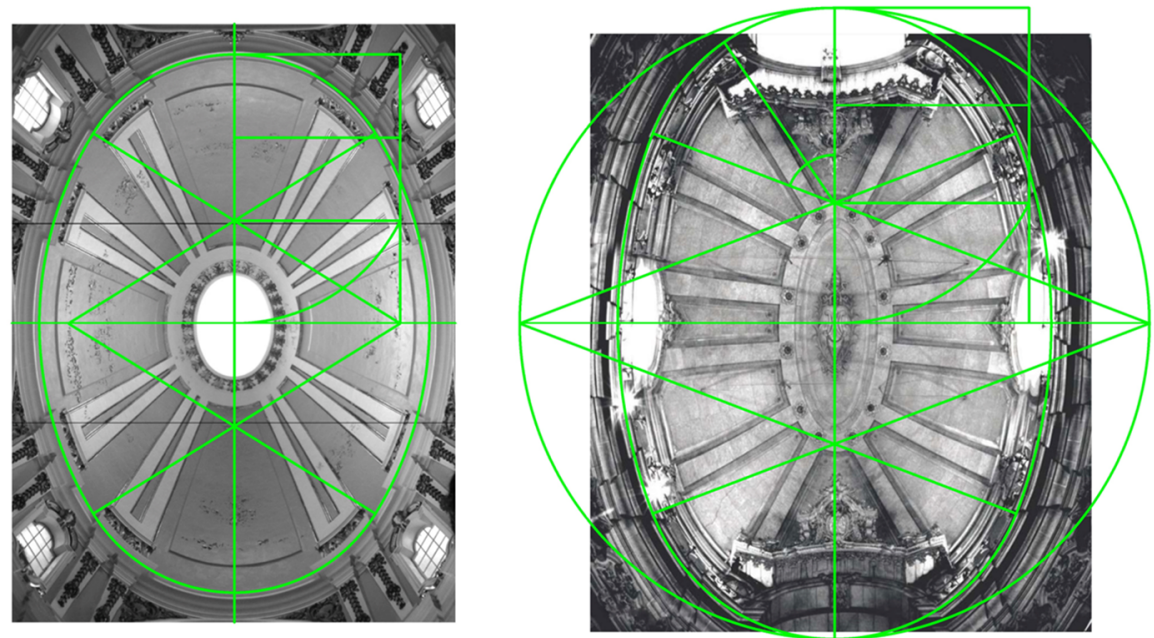

major axis $=19,4 \mathrm{~m}-$ minor axis $=13,4 \mathrm{~m}$

Fig. 14 Comparing St. James (F. Carapecchia, 1710) and Clérigos (N. Nasoni, 1731) domes. Images: (Varela 2006: 62, 88), reproduced with permission 


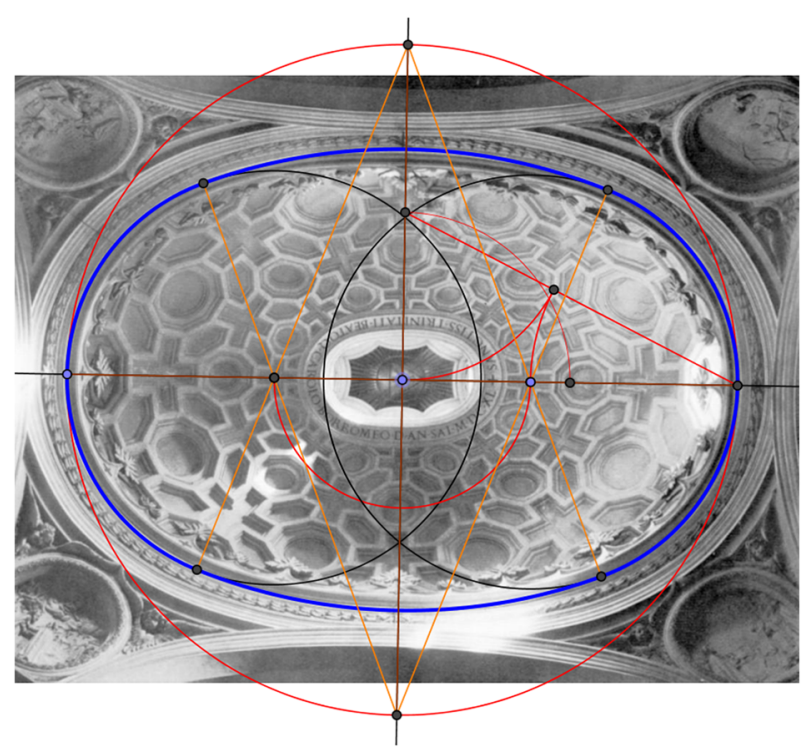

Fig. 15 The oval used in Clérigos's plan superimposed on San Carlino's dome. Geometric construction: author. Photo: Kim Williams

(Fig. 15). Furthermore, the same oval reappears later in the design of the central cortile of the palazzo Carapegna. ${ }^{14}$

We know that there was a preliminary plan for the Clérigos Brotherhood that included the actual church with a smaller apse. According to Varela (2006: 72-75), this primitive apse could have been similar to St. James. The decision to give 'more length' to the apse in order 'to be able to make tribune on the altarpiece', to erect the new sacristy, the house-infirmary, workshops and a new 'bell tower', was only made in 1753, with Nasoni submitting the drawings the following year (Hierro Lopes et al. 2013: 154-155). This was the beginning of the second phase of the works, which led to the final form of the building.

Although the altarpiece and the wall treatment of the apse, as well as the integration of the organs, was concluded after Nasoni's death by Manuel António Porto, I am convinced that in Nasoni's plans the two organs were already foreseen, as in the Cathedral of Porto or the Cathedral of Lamego, where he also placed two organs, face to face. It is worth asking where they were in the first design. The most obvious answer seems to be the high-choir and therefore I believe we shouldn't assume that there was more than one. With the expansion arises the idea of the two organs, in order to guarantee, by means of axial symmetry, the best-tuned visual and musical equilibrium.

When, in 1731, during the absolutist rule of João V, the Dean of the Cathedral of Porto presented Nicolau Nasoni's design for a Church and new home to the Clérigos Brotherhood-a community which was created in the beginning of the century resulting from the merger of three Brotherhoods, one of which was the

\footnotetext{
${ }^{14}$ See tavole XCIV in Paolo Portoghesi's book on Borromini (1984: 207).
} 
Congregation of the Oratory-he must have been really proud! The novelty and originality of the building, fulfilling a noble charitable mission, was remarkable and the entire initiative was assumed as a counterpoint to the Royal enterprises, with whose scale it could not compete. But the methodology was similar: as in the Royal Palace-Convent-Basilica of Mafra (Fig. 16) - the Portuguese Escorial-the architect would be a foreigner, his imagination equal to the achievement, and his art grounded in a solid training perfumed by the Roman Baroque.

The Brotherhood Board, composed of 120 brothers, unanimously approved the plans for the building, which included the oval Church.

I think the Oratorians, very influential in the Brotherhood, might have welcomed the idea with particular enthusiasm, as the Church represented the modern version of a true Oratory. The oval layout was, indeed, a feature that clearly surpassed the rectangular design of their former Mannerist church in Porto, the Congregados.

If an Oratory is associated with a particular musical performance we might ask whether, during the eighteenth century, an oratorio was ever performed in the oval oratory of Clérigos?

Unfortunately, I have not found any answer to this question. What we do know is that during the celebrations associated with the Royal Family, there was a set of very different events, including operas and comedies performed in theatres or public spaces, and the Procession, the Solemn Mass and the Te Deum Laudamus in sacred spaces. Although the Cathedral was the most obvious choice for these events, other churches also served as their setting, including the church of Clérigos.

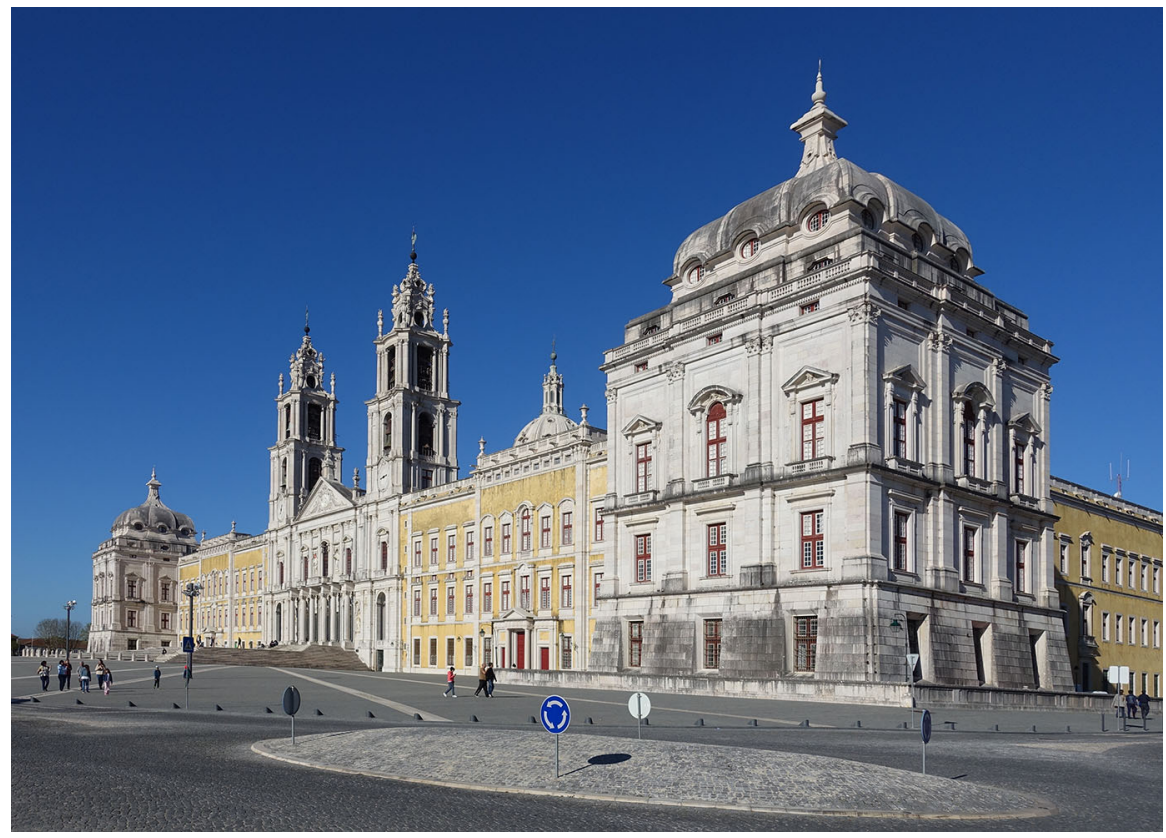

Fig. 16 Royal Palace-Convent-Basilica of Mafra. João Frederico Ludovice, 1717-37. Photo: author 
And what about the oratorio? As I couldn't find a good answer for Clérigos, it occurred to me to massage History a little bit and assume that there would have been possible to hear in Clérigos the contemporary oratorio La Giuditta of 1726 (Vieira de Carvalho 2005), by Francisco António de Almeida, a Portuguese musician who studied in Rome from 1722 to 1726, with a grant awarded by João V, where one of his teachers was, precisely, Bernardo Pasquini.

Although the dates could match, the likelihood that this oratorio was performed at Clérigos is practically nil, but one thing we know for sure: the premiere occurred at the Oratorio dei Filippini in Rome! And I believe that the perfect match between music and space surely felt in Rome, would have been experienced in Porto as well.

Acknowledgements I wish to thank Father Américo Aguiar (President of the Clérigos Brotherhood), Marco Brescia (organist and musicologist), Luís Soares Carneiro (architect), Cristina Fernandes (musicologist), Tiago Manuel da Hora (musicologist), Sofia Lourenço (pianist), Manuel Montenegro (architect), Rosana Orsini (soprano and musicologist), Maria João Pereira (astrophysicist), João Carlos Santos (architect), Rui Soares (organist), and Pedro Varela (architect). I am also deeply grateful to the reviewers, and especially to Arch. Kim Williams for the careful analysis of the text, all the suggestions and the English revision.

\section{References}

Bagenal, Hope and Alex Wood. 1931. Planning for good acoustics. New York: E. P. Dutton and Company Inc. Publishers.

Caramuel de Lobkowitz, Juan. 1678. Architectura Civil Recta y Obliqua considerada y dibuxada en el Templo de Ierusalen. Vigevano: Emprenta Obispal por Camillo Corrado.

Carneiro, Luís Soares. 2002. Teatros Portugueses de Raiz Italiana. Porto: Ph.D. thesis presented at FAUP.

De Lucca, Denis. 1999. Carapecchia. Master of Baroque Architecture in Early Eighteenth Century Malta. Valletta: Midsea Books Ltd.

Duvernoy, Sylvie. 2015. Architecture and Mathematics in Roman Amphitheatres. In: Architecture and Mathematics from Antiquity to the Future, eds. Kim Williams and Michael J. Ostwald, vol. I, 189-199. Cham: Springer.

Fludd, Robert and Matthaus Merian. 1618. Utriusque cosmi maioris scilicet et minoris metaphysica, physica atque technica historia in duo volumina secundum cosmi differentiam diuisa authore Roberto Flud aliàs de Fluctibus, ... Tomus primus-secundus!...: Tractatus secundus de naturae simia seu technica macrocosmi historia in partes. Ære Iohan-Theodori de Brÿ.

Goethe, Johann Wolfgang von. 1839. Conversations with Goethe in the Last Years of His Life. Trans. S. M. Fuller. Boston: Hilliard, Gray, and Company.

Gomes, Paulo Varela. 2001. Arquitectura, Religião e Política em Portugal no Século XVII. A Planta Centralizada. Porto: FAUP Publicações.

Hersey, George L. 2000. Architecture and Geometry in the age of the Baroque. Chicago and London: The University of Chicago Press.

Hierro Lopes, Beatriz and Francisco Queiroz. 2013. A Igreja e a Torre dos Clérigos. Porto: Irmandade dos Clérigos.

Huerta, Santiago. 2007. Oval Domes: History, Geometry and Mechanics. Nexus Network Journal 9(2): 211-248.

Kircher, Athanasius. 1650. Musurgia Universalis: sive Ars magna consoni et dissoni in X libros digesta... Rome: Typographicum haeredum Fratelli Corbinetti.

López Mozo, Ana. 2011. Ovals for Any Given Proportion in Architecture: A Layout Possibly Known in the Sixteenth Century. Nexus Network Journal 13(3): 569-597.

Mazzotti, Angelo A. 2014. What Borromini Might Have Known About Ovals. Ruler and Compass Constructions. Nexus Network Journal 16(2): 389-415.

Mersenne, Marin. 1635-36. Harmonicorum libri in quidis agitor de sonorum natura... Paris: Baudry. 
Norberg-Schulz, Christian. 1977. La signification dans l'architecture occidental. Bruxelles: Pierre Mardaga Éditeur.

Patte, Pierre. 1782. Essai sur l'Architecture Théatrale. Paris: Chez Moutard.

Pereira, José F. 1993. Resistências e aceitação do espaço barroco: a arquitectura religiosa e civil. Moura, Carlos. História da Arte em Portugal. O limiar do barroco 8. Lisboa: Publicações Alfa S.A., 9-65. Pimentel, António F. 2002. Arquitectura e Poder-O Real Edifício de Mafra. Lisboa: Livros Horizonte. Portoghesi, Paolo. 1984. Francesco Borromini. Milano: Electa Editrice.

Rosin, Paul. 2001. On Serlio's constructions of ovals. The Mathematical Intelligencer, 23(1), 58-69.

Smith, Robert C. 1966. Nicolau Nasoni. Arquitecto do Porto. Lisboa: Livros Horizonte.

Stehman, Jacques. 1978. História da Música Europeia. Amadora: Livraria Bertrand (Portuguese trans. of Histoire de la Musique européenne des origines a nos jours. Editions Marabout Collection Universite $\mathrm{Mu} \mathrm{n}^{\circ} 67$. Verviers: Gérard et Cie.., 1964).

Varela, Pedro. 2006. Espaços de planta elíptica na arquitectura religiosa: o caso da Igreja dos Clérigos no Porto. Porto: Final Dissertation presented at FAUP.

Vieira de Carvalho, Mário. 2005. 'Giuditta' de Francisco António de Almeida: um 'oratorio erotico'. In 'Por lo impossible andamos': a Ópera como Teatro. De Gil Vicente a Stockhausen. Porto: Âmbar, 217-222.

Wren, Christopher, Ames, Joseph, Wren, Stephen. 1750. Parentalia: Or, Memoirs of the Family of the Wrens; Viz. of Mathew, Bishop of Ely Christopher, Dean of Windsor \& Co. But Cheifly of Sir Christopher Wren. London: T. Osborn [etc.].

Xavier, João Pedro. 2013. Gli spazi della musica e le musiche dello spazio. Margagliotta, Antonino, Failla, Luigi (Eds.). Composizione, Musica, Architettura. Casa Editrice Libria Melfi (Italia), 58-69.

João Pedro Xavier is an architect and Associate Professor at the Faculty of Architecture of the University of Porto (FAUP). He received his degree in Architecture from FAUP, a PhD in Architecture in 2005, and has been licensed as an architect at the College of Architects in Porto since 1986. He has won academic prizes, including the Prémio Florêncio de Carvalho and the Prémio Eng. António de Almeida. He worked in Álvaro Siza's office from 1986 to 1999. At the same time, he established his own practice as an architect. He is the author of Perspectiva, perspectiva acelerada e contraperspectiva (FAUP Publicações 1997) and Sobre as origens da perspectiva em Portugal (FAUP Publicações 2006). Xavier has always been interested in the relationship between architecture and mathematics, especially perspective. He has published several works and papers on the subject, and presented conferences and lectures. He was co-director of Nexus 2010 in Porto. 